\title{
A Note on Legal Language and Brazilian Orthography and Names
}

Language, especially the language of law in the eighteenth and nineteenth centuries, plays a central role in this study. The terms used in this book frequently differ from legal terminology currently in use in Brazil. Deviation often reflects more than merely a linguistic shift, however. Today, the legal concepts have often changed from what they were two hundred years ago. Consequently, English cannot always supply precise equivalents. If they exist in Anglo-American law, equivalent terms may imply different outcomes. Consequently, I have sometimes used archaic English to render language derived from a Luso-Brazilian legal tradition, as in the practice of "calling" the legitimate heirs to succeed. Otherwise, Brazilian readers will discover constructs that are central to discussion, such as "qualidade," an individual's quality of birth, no longer matter in their inheritance system. In matters of inheritance, Jack Goody has reminded us, "It is not easy to be precise unless we are technical." Although I have translated Portuguese legal terms into English wherever they do correspond to Anglo-American legal concepts, there is a strong case to be made for retaining Portuguese where English "synonyms" either do not exist or imply different constructs, meanings, or outcomes. Rather than trying to harmonize linguistically what are really notions fundamentally alien to Anglo-American usage today, I have deliberately left a small number of those terms dissonant by retaining Portuguese terms. To do otherwise would be to blunt, to distort and misrepresent, or to confuse analysis of change over the century this book addresses.

Readers may initially be puzzled as to why I have not spoken consistently throughout the book of "illegitimacy" and "illegitimate" offspring, and, instead, alternated the latter with terms like "non-legitimate" or "out-ofwedlock." One reason is to avoid reliance on the dichotomy familiar from Anglo-American law that rigidly opposes "legitimate" to "illegitimate." LusoBrazilian legal tradition demonstrated a spectrum of intermediate positions 
rather than a bifurcation of legal birth status. Another is to favor deliberate usage of "natural" and "spurious" offspring, as opposed to merging both as "illegitimate offspring." Sometimes even much finer discrimination is warranted, for alternate terms were operative in Brazil and Portugal until the twentieth century: incestuosos, adulterinos, and sacrílegos, as well as quaesitos and expostos. Basically, however, I have retained the language Brazilians used to designate those born out of wedlock for the period under study, because I wanted to convey how individuals from all walks of life labeled and thought about people who lacked legitimate birth. Although, historically, AngloAmerican legal tradition has not discriminated finely among those who were illegitimate, it is also the case today that even Brazilians are much less likely to apply the finely tuned discrimination that was second nature to their grandparents or great-grandparents.

"Illegitimate" is a term taken from the civil law. Normally, Brazilian vernacular speech during the Empire and colonial period preferred the fine discrimination supplied by canon law. Although "illegitimacy" and "illegitimate" were not alien to the vocabulary of either jurists or ordinary people throughout the period this book spans, the language of canon law supplied the analytical constructs of an individual's "quality of birth." Those constructs, received in national positive law, underlay the social categories people regularly used in vernacular speech. Therefore, a crown jurist in Pombal's Lisbon and an illiterate farmer in Brazil's era of independence spoke the same language when they identified an individual as a "natural" child rather than an "illegitimate" child. In other words, religion, as much as inheritance law, inculcated the vocabulary of heirship used in this book and accounted for why the language of canon law penetrated popular speech. Rather than applying constructs of illegitimacy contemporary with the twenty-first century, I have tried to suggest those appropriate to the context spanning 1821 to 1889. The result is greater nuance and cultural shading, not to mention legal precision.

In one case, I have opted to retain a Latin term as the equivalent for Portuguese usage when a perfectly acceptable English equivalent exists: $a b$ intestato. The reason that I have not adopted "intestate" as a translation is that it would only distract North American and British readers from appreciating the fundamental difference between their system of succession and the LusoBrazilian system analyzed in this book. My initial effort to isolate the essence of what nineteenth-century legal commentators usually wrote as "abintestado" led me to discard "intestate," the better to focus on what a LusoBrazilian context implied. The term conjures up a fundamental difference in an Anglo-American legal tradition-nearly the opposite meaning in a Luso- 
Brazilian legal tradition. " $A b$ intestato" is synonymous with "legitimate" or "natural" succession and it presumes the natural order of events in LusoBrazilian succession. That order is one where a will is unnecessary, because the rules of forced heirship determine the division of an estate and offer reassurance that the identity of the heirs is already known. In Anglo-American legal tradition, on the other hand, "intestate" implies a lapse-the failure to write a will. "Intestate" therefore can imply a family catastrophe, or at least a dissonant order of events that threatens to overturn normative expectations about heirship.

Finally, "intestate" implies the state's intervention is needed to identify and verify the authenticity of the heirs in an Anglo-American legal tradition. Those heirs, like wills, must be proved in a court of law. In the LusoBrazilian legal tradition relevant to this volume, as opposed to the colonial period, the state ceased to play a marginal role vis-à-vis the identity of the heirs in legitimate or natural succession, by virtue of the greater attention it paid to taxing those heirs. However, $a b$ intestato succession still took place without the state's intervention, a circumstance largely explaining why, with one exception, no tax was levied on ab intestato heirs by Brazil's imperial government until the second half of the nineteenth century.

$A b$ intestado succession in Luso-Brazilian law was also carefully distinguished from testamentary succession, the latter being the exception rather than the rule-and again, the opposite of Anglo-American practice. Hence, by relying on the device of " $a b$ intestato" throughout the text, I am encouraging North American and British readers to stop thinking in terms of the assumptions, concepts, and rules of Anglo-American succession. I am asking them to don the mentality of an eighteenth-century civil law tradition, one where the heirs were already known and the lack of a will frequently defined the best scenario.

Brazilian orthography has varied considerably since the eighteenth century. The text of this book has modernized the spelling of archaic legal terms as well as the titles of legal codes, but left them unaltered in the notes and bibliographies. I have, however, spelled the names of individuals mentioned in the text of this book according to the usage in vogue when they were alive, meaning that names have usually been left consistent with the orthography specific to the sources cited in the notes. Given the latest orthographic reform that removes many diacritical marks from Portuguese, early nineteenthcentury spelling more closely approximates early twenty-first-century spelling. Because historically there were no firm rules governing how people in Portugal and Brazil projected their names, not only the spelling of names 
but also the ways that individuals idiosyncratically manipulated their discrete name sets varied considerably. To a much lesser extent, this phenomenon continues to be true in Brazil down to the present. This is to say that Portuguese often prefers first names, even nicknames, wherever they are sufficiently uncommon or unique to obviate use of a concatenation of family names. Consequently, sometimes I have applied a lone rule of thumb that is still used in Brazil today. Individuals with uncommon or unique first names are often identified on a first-name basis. Thus Aureliano de Souza e Oliveira Coutinho is frequently identified as "Aureliano," just as in the 1980s the Brazilian press referred to Prime Minister Margaret Thatcher as "Margaret." Alternatively, his name is shortened to "Souza Oliveira," the parliamentary redactor's usage. In homage to Candido Mendes de Almeida, imperial Brazil's great jurist, he is identified obliquely in this book by the name Brazilians still use to refer to him, given his fame and the uniqueness of his first, Brazilian edition of the Philippine Code: "Candido Mendes."

Like the politicians mentioned in this text, the jurists discussed herein are identified initially in terms of their full names and then only mentioned by the short forms they routinely used to refer to each other in their own citations in legal commentaries. Thus Manoel de Almeida e Souza de Lobão was universally identified simply as "Lobão," and Lafayette Rodrigues Pereira became "Lafayette." The list of Legal Primary Sources Cited facilitates the referencing of their full names for readers. A decided preference for unique first names also implied that individuals who possessed extremely common given names frequently opted to project only one or more of their family names. They either omitted their given names altogether or they reduced them to initials. Finally, I have discriminated by given names several legislators in the same delegation who shared the same family name, due to being close relatives.

Politicians in this study are identified by their noble titles only where relevant in the period under study. I have declined, except in a few instances, to employ the convention of identifying anyone as a future bearer of a title. The title of the chief executive of a province throughout the imperial period was "president." I have retained the honorific "dom," which the Portuguese and Brazilians employed in lieu of the title, "King," abbreviated as in "D. Pedro I." Otherwise, I have followed standard usage and applied "dom" to several prelates of the Brazilian church. As the preceding volume of this study clarified, the honorific "dom" still applied widely at independence, to all individuals who either were noble by descent or were ennobled by the monarch. Women were analogously identified as "dona." Those whose nobility was merely civil, conferred by the law and therefore "secondary," did not enjoy 
the right to be addressed as "dom." With independence, use of "dom" rapidly eroded. By the close of the Regency, in 1840, the honorific was confined largely to the royal family and prelates of the church.

The monetary unit of the Empire was the mil-réis, written 1\$ooo. The conto equaled one thousand mil-réis and was written 1:00o\$ooo, conventionally abbreviated as 1:00o\$.

The laws that comprise the primary sources for this volume are identified in terms of a myriad of designations originating in the usage of the Portuguese crown. Throughout Brazil's colonial history, statutory law, the most important source cited herein, was attributed to the sovereign and identified as "legislation," notwithstanding the absence of a legislature. Statutes were issued in the form of an alvará synonymous with "law" in English. After Brazilian independence, either "law" (lei) or "decree" (decreto), and even "decreelaw" (decreto-lei), supplanted "alvará." However, the latter term continued to refer to crown law adopted prior to 1822 . The indiscriminate use of both "law" and "decree," sometimes for the same statute, may confuse readers. It also confounded jurists, who understood "law" and "decree" were virtually synonymous. The persistence of this dualism seems to have originated in the monarch's historic loss of his role as "the Legislator" in the 1820s. In Portugal, lamented legal historian João Gomes B. Câmara, "the inexplicable distinction between 'law' and 'decree' was not resolved until 1936," when "law" triumphed. He offered a fine point doubtlessly accounting for the persistence of a dual nomenclature. A decree emanated from the legislature, but only the monarch's sanction, or signature, made it a "law." In Brazil's case, the abolition of the monarchy in 1889 brought this duality to a close.

The other main source of law cited in this volume is, of course, the Ordenações Filipinas of 1603, the final of four compilations of Portuguese positive law that were promulgated as national codes of law between 1446 and 1603 . Generically, these codes were referred to as "the Ordenações do Reino"-or simply the "Ordenações"-implying also the particular code currently in effect. During Brazil's Second Empire (1840-1889), usage moved away from the emphasis on what was, after all, a code derived from "the Kingdom of Portugal," to favor the politically less loaded alternate term, "Código Filipino," or Philippine Code. References to the Ordenações Filipinas of 1603 herein refer to Candido Mendes de Almeida's monumental 14th edition, published in 1870, the first to offer commentary in terms of Brazilian law: Codigo Philippino ou Ordenações do Reino do Portugal ... . Otherwise, law in both colonial and early imperial Brazil consistently drew on administrative orders and clarifications, such as avisos, that were issued by the king's ministers or, in imperial Brazil, by the cabinet ministers associated with parliamentary gov- 
ernment. Procedural law, such as that pertaining to high crown courts like the Tribunal of the Mesa do Desembargo do Paço, usually was defined in discrete "regimentos" or sets of regulations having the force of law. By the same token, the decisions of high crown courts, termed "estilos," frequently were cited as law throughout colonial and imperial centuries, given that the 1828 Judiciary Act perpetuated them in force throughout the Brazilian Empire. A list of abbreviations for these administrative and judicial forms of law has been prepared for readers.

The published sources used to write this book have been divided into two parts, one that pertains exclusively to legal primary sources, consisting of commentaries, treatises, and notarial manuals, or codes and collections of laws, gathered together as Legal Primary Sources Cited. Remaining sources, including legal histories, appear in Other Sources Cited. The lengthy nature of legal titles means that several have been abbreviated. Legal citations in the notes employ the standard abbreviations appearing in works contemporary to the nineteenth century. Therefore, I have also cited a legal commentary's discrete divisions: book, volume, part, chapter, title, section, and item number. Page numbers appear in parentheses, given that editions vary and the footnotes are often lengthy. 


\title{
SURPRISE HEIRS
}

\author{
Volume 2
}

Illegitimacy, Inheritance Rights, and Public Power in the

Formation of Imperial Brazil, 1822-1889

A civil code is not solely a work of science and talent. It is, above all, a work of customs, of traditions-in a word, of a people's civilization. 
